\title{
15
}

\section{Full Circle: Les Guérillères}

\author{
we bend \\ At different temperatures... \\ Yes, fusion is possible \\ but only if things get hot enough-
}

-Cherríe Moraga, "The Welder"

I have been saying that communal narrative voices are produced from intersections of social and formal possibilities. I also proposed that although contemporary feminists have created a political context that makes female community more viable, novelistic conventions of coherence and continuity inhibit the construction of communal narrative forms. My final chapter takes license to return to a somewhat earlier moment when the convergence of two differently radical movements-respectively for an international feminist revolution and a revolution in narrative-creates what may still be the most inclusive, uncompromisingly feminist communal voice in Western literature in a work that also sounds a death knell for that literature. Monique Wittig's Les Guérillères (1969), a work in the countertradition of the French nouveau roman or antiroman, was inspired by the May 1968 political actions in Paris, when women participants recognized that "the vast majority of their male comrades were as deeply phallocratic as the bourgeois enemy." From the vantage point of two decades and an increasingly global consciousness, however, Les Guérillères also signifies, in ways it clearly did not "intend," the limits even of feminist

1. Elaine Marks and Isabelle de Courtivron, New French Feminisms: An Anthology (Amherst: University of Massachusetts Press, 1980), 30. 
Western discourse, which unwittingly reproduces its own cultural and linguistic dominance.

Both formally and representationally, Les Guérillères constitutes an infinitely expandable community of women at once united and diverse, a community at once mythic and panhistoric, existing in no time and all time, described primarily in a nonspecific continuous present tense. But although Les Guérillères begins with female community (or communities), it does not begin with communal voice; rather, it represents the process by which female community develops such a voice. When at the very end of the book the authorial narrator explicitly joins this "we," the narrative also moves from a utopic nowhere/everywhere to contemporary (realist) time and space, in a gesture that is at once a sign of political urgency and an ideological trap.

Les Guérillères goes far beyond any work I have described in this section in rejecting the demands of realist plot and the entire apparatus of what Roland Barthes called "readerly" narrative-identifiable settings, narrative linearity, individualized characters. Physically, the text appears as discontinuous paragraph-long sections whose positioning reflects no absolute continuity in time or theme. The "characters" are a collectivity of "guérillères"-a neologism that evokes not only warfare but healing (guérir). What exists of plot is a loose, dialectical division. First the text represents one or many autonomous female communities, describing the myths, rituals, symbols, beliefs, and practices of the self-renewing culture that helps them "beware of dispersal" and "remain united like the characters in a book." ${ }^{2}$ In midtext there begins a series of violent struggles against male dominance from which the women, in unity with those "young men" who are willing to understand their struggle, finally emerge victorious. These large developments are impossible to pin to a single textual moment, for the novel's resistance of realism allows the sexual struggles to be occurring at different moments, in different places, on different fronts. What unites the discourse is the fact of community-which, however diverse, is always "elles." The antiphallic signifier of this unity is the "O": an "infinite sphere whose centre is everywhere, circumference nowhere" (69/97), whose movements are revolutions, "the sign of the goddess, symbol of the vulval ring" (27/35) which represents the mirror, the ego, the sun, fullness and emptiness, completion and

2. Monique Wittig, Les Guérillères (Paris: Les Editions de Minuit, 1969), 82; English translation by David Levay (New York: Avon, 1971 ; reprint, Boston: Beacon, 1985), 58. Further references to both editions will appear in the text, with the English cited first. 
renewal, perfect equality and equilibrium, union without hierarchy, closure "without limit" (69/97).

The absence of hierarchy and limit also constitutes the ground on which Les Guérillères overturns conventional notions of narrator and character. The text's "collective protagonist" and ultimately its narrative authority is the inclusive, infinitely expandable pronoun "elles." The very use of this pronoun is a radical insertion, a form made rare by androcentric language rules that use the feminine plural only for a wholly female community; that the "elles" ultimately embraces not only all women but ultimately also certain men constitutes a pointed reversal of French practice. Wittig chooses "elles" rather than "femmes" because, as Mistriss Henley has made painfully clear, the double meaning of "femme" makes the sign of woman's identity always already the sign of her subjection-and her silence-as wife.

This "elles" is not, however, present simply as an anonymous, idealist abstraction that could be (mis)taken for a homogeneous community; it materializes in the blocks of female names printed in large capital letters on every few pages of the book. These "single forename[s]" (13), which link the women horizontally in relation to one another rather than vertically in relation to men, posit what Winifred Woodhull calls an antigenealogy, a radical alternative to bourgeois culture and also, I would add, a radical challenge to the bourgeois novel, because "identity can only be thought in terms of the collectivity." 3 The names stand alone in the center of the page like small communities, each uniting women of present and past, "East" and "West," fiction and history-literary and historical names like CLARISSA, CHRYSEIS, ISOLDE, LAMIA; ordinary names like LOUISE, DORIS, ANIKO; and invented names that feminize the masculine, underscore the revolutionary imperative, or signify woman's "place" (HEGEMONIE, ALIENOR, NAUNAME, HEMANE, OSEE, CALAMITA, VILAINE, ANGE), yielding this kind of typical block:

\author{
METTE KHADIOTA MICHAELA \\ PHANO HUGUETTE LELIA \\ SIDONIA OMAYA MERNEITH \\ INIBRINA WUANG-QIANG \\ ASPASIA HANNAH LETITIA \\ NORA BENOITE RADEGONDE
}

3. Winifred Woodhull, "Politics, the Feminine, and Writing: A Study of Monique Wittig's Les Guérillères and Brouillon pour une dictionnaire" (Ph.D. diss., University of Wisconsin, 1979). 
The gynomythography that Les Guérillères constructs mirrors this project of cultural diversity: the women honor the goddesses Amaterasu and Cihuacoatl (27/34-35), re-create Prometheus and the Round Table as female legends $(45 / 61-62)$, remember the warrior Nü Wa's victories $(8 \mathrm{o} / 112-14)$, Lei Zu's discovery of silk $(81 / 115)$, the victories of Vlasta and "the young women of Bohemia" $\left(11_{4} / 1_{5}\right)$. Freed from conventional realist continuities of plot, character, and history, Les Guérillères can insist on a community that crosses spatial, temporal, and imaginative boundaries. However, in spite of its evident intentions, the text remains European in its cultural base: French names and Western myths dominate, so that the Les Guérillères cannot be said to authorize a global community. This problem is most apparent when the text moves into a (rare) moment of quasi-conventional narrativity by naming one of the "elles" with an individual identity: Lucie Maure, Marthe Vivonne, Valerie Céru, Marthe Ephore, Fabienne Jouy, Marie Viarme. I will suggest below that such slips into realist narrativityinto the individuation of realist character, time, and space-inevitably construct some kind of cultural hegemony.

Open and expansive at least in theory, however, the "elles" is not merely the collective "protagonist" of Les Guérillères but ultimately its collective authority and its collective voice. Until its last paragraph the narrative voice of Les Guérillères is technically heterodiegetic: a "third person" recounts what the women say and do. But this is not the conventional authorial voice that looks down upon and interprets a community. The text avoids the markers that suggest hierarchies of voice; there are no quotation marks, indentations, or shifts between the past tense of a narrator and the present tense of characters. Unlike the authorial narrators I discussed in Part I, the narrator of Les Guerillères restricts herself entirely to acts of representation: she is an anonymous and undramatized presence that records what "elles" do and say. Although such a narrator resembles formally the "voiceless" camera eye constituted by nouveaux romanciers like Alain Robbe-Grillet and Marguerite Duras, she serves here as a kind of scribe, recording a culture's deeds and words. "Elles" are the source of legends and stories, decisions, warnings and reminders, aphorisms and judgments, political analyses and rituals, all of which the narrator simply passes on.

In substituting this communal source for the individualist "author" of traditional fiction, the text also substitutes oral discourse and provisional textuality for the reified corpus (corpse) of Western patriar- 
chy's written texts. What the "elles" say is contingent not because there is any higher authority but because the community's own truths must continually change. Thus the women decide at one point that their own discourse "denote[s] an outworn language" and that "everything must begin over again [il faut tout recommencer]" (66/93-94). This provisional nature even of communal authority is evident not only in what the women say but in what they write in the "grand registre" and the little "féminaires" that are the community's sacred texts (14/ 17). Unlike the sacred texts of the fathers, the feminaries are not authorized from outside or above the community. It seems not to matter whether there are "multiple copies of the same original" or "several kinds" (14/17) because all textual authority is limited despite the obvious importance of (provisional) texts. Texts must remain continually (re)inscribable, and by those very persons for whom they hold authority: "when it is leafed through the feminary presents numerous blank pages in which they write from time to time" $\left(15^{/ 1} 7_{-1} 8\right)$. No text is the definitive text; there must be no definitive text.

It is clear that the "feminary" and the "great register," with their rejection of conventional linearity, describe Wittig's own book. Like the feminary, Les Guérillères "consists of pages with words printed in a varying number of capital letters. There may be only one or the pages may be full of them. Usually they are isolated at the centre of the page, well spaced black on a white background or else white on a black background" (15/18). And like the "great register," which lies always open like a family Bible, it is "useless to open" Les Guérillères "at the first page and search for any sequence. One may take it at random and find something one is interested in." Yet, "diverse as the writings are they all have a common feature" $(53 / 74-75)$. A living and changing record of community, the "great register" continues to be written even as it is being read: "Not a moment passes without one of the women approaching to write something therein. Or else a reading aloud of some passage takes place" $(53-54 / 75)$. This suggests that the narrative voice of Les Guérillères may itself not be singular; that any number of "elles" are its scribes, again dissolving the conventional hierarchy between narrator and characters. And if readers are writers, and all "elles" are authorized to write, then Les Guérillères also turns all willing (female and male) readers into writers of "féminaires," scribes of a living and ever-changing collective discourse that is set against the patriarchal text that derives its authority from its implicitly fixed, transcendent voice. Here textuality exists only to serve 
the women; what is important is the authority over discourse, which includes the right not only to constitute but to discard texts. When the feminaries "have fulfilled their function [rempli leur of fice]," when the "ancient texts" seem "outdated" (49/67-68), they must be let go. Hence too the emphasis on the temporary, on spoken discourse-the ubiquitous "elles disent"-rather than on writing ("elles écrivent").

But while the "elles" exists from the beginning of the text as the collective protagonist, the women are not from the outset a collective voice. Rather, Les Guérillères traces through its own syntax and semantics the very conditions for the emergence of communal voice. At first the women are "huddled [pressées] against each other" and have no voice at all: they "open their mouths to bleat or to say something but no sound emerges" (30/38). The early sections of the book do not employ the "elles disent" at all; the narrator records the women's actions but not their words. We are told that the women shout, laugh, cry, and repeat stories and legends, but these verbal acts are described rather than transcribed. Several of these early legends themselves concern voice; the stories of the siren and the echo and the first introduction of the feminaries appear very early in the text $\left(14^{/ 16}-\right.$ 17).

Significantly, the textual moment in which the women are first said to speak coincides precisely with their recognition and celebration of their sexuality as they name and (re)claim the female body and rewrite a culture in which woman's body is the (unspeakable) source of her silencing: "The women say [elles disent] that they expose their genitals [leurs sexes] so that the sun may be reflected therein as in a mirror. They say that they retain its brilliance. They say that the pubic hair is like a spider's web that captures the rays" (19/24). It is in naming the body that the women begin both to speak and to write (22/29). Implicitly such a conjunction of voice and sexuality refuses both the heroine's text, in which the woman who gives her body gives up her voice, and the representations of female community-in Cranford, Herland, The Country of the Pointed Firs, and even Deephaven-in which female sexuality is denied. In this way Les Guérillères also makes clear why female voice is a crucial signifier for female authority and autonomy, why Hélène Cixous insists that when you "censor the body," you "censor breath and speech at the same time."

4. Hélène Cixous, "The Laugh of the Medusa," trans. Keith Cohen and Paula Cohen, in Marks and Courtivron, New French Feminisms, $25^{\circ}$. 
Although Les Guérillères has at this point established a collective female cultural authority, the narrator still represents the discourse of the "elles" in indirect forms. Until more than halfway through the text, nearly all of the collective knowledge and wisdom of the "elles" is narrated through tagged indirect discourse, a form that does not, like free indirect discourse, rely on even the flavor of the speaker's own words: "the women say that [elles disent que] they expose their genitals" (19/24); "the women say that [elles disent que] any one of them might equally well invoke another sun goddess" (27/35); "the women say that [elles disent que] references to Amaterasu or Cihuacoatl are no longer in order" $(3 \mathrm{o} / 38)$; "they say that [elles disent que] as possessors [porteuses] of vulvas they are familiar with their characteristics" (31/41); "they say that [elles disent que] the clitoris has been compared to a cherrystone, a bud, a young shoot, a shelled sesame" (32/42); "the women say that [elles disent que] the feminaries give pride of place to the symbols of the circle, the circumference, the ring, the $\mathrm{O}$, the zero, the sphere" $\left(45^{/ 61}\right)$; "the women say that [elles disent que] they perceive their bodies in their entirety," that "they do not want to become prisoners of their own ideology" (57/80).

This indirect discourse creates a slight distance between the words of "elles" and the narrative voice that at the very least denies the women the fullness of textual voice and, it seems to me, renders their authority subtly contingent. But ultimately the narrative shifts definitively into a direct discourse that signals the full authorization of the women to speak for themselves. It is ironic and significant that this textual voice is born in revolutionary politics: under the pressure of domination, the women construct a generalizing didactic authority directed at a collective female narratee and designed to empower the women against male dominance. At the same time, the pronominal referents for "elles" become intermingled and interchangeable: they are at once "we," "I," and "you": "The women say [elles disent], the men have kept you at a distance, ... put you on a pedestal, constructed with an essential difference... described you as they described the races they called inferior" (100-102/146); "the women say [elles disent], you are really a slave if there ever was one" (106/153); "the women say [elles disent], I refuse henceforward to speak this language" (107/153); "the women say [elles disent], unhappy one, men have expelled you from the world of symbols [signes]" (1 1 12/162); "they say [elles disent], the language you speak is made up of words that 
are killing you" (114/162); "the women say [elles disent], whether men [ils] live or die, they no longer have power" ( $115 / 165)$; "they say [disent-elles], we must disregard all the stories" (134/192); "they say [elles disent], if I relax after these great achievements I shall reel drunk with sleep and fatigue" (136/197).

Finally entire passages come to be narrated directly, without even "the women say" to introduce them, as all textual authority combines into a single collectivity that embraces the personal and the authorial, the "I" and "we" as well as the "you" and "they," all pronouns collapsing into communality. The direct discourse becomes, in aggregate, the ultimate "maximizing" text in which generalization does not simply underscore representation but becomes that which must be represented. In other words, Les Guérillères remaximizes narrative by writing the ideology of feminist revolution: the rewriting of maxims is part of the revolutionary project and hence of narrative. By the time the women triumph, their authority has become entirely communal and it has become clear that voice is resistance, and discourse one ground on which the "battle of the sexes" must be engaged.

This newly forged community is thus not the "elles" of an old and peaceful order, the "elles" who do not have even to imagine themselves as a "we" against a "they"; it is a revolutionary or postrevolutionary "we" in which "she" also includes "he." That is, the ultimate communal voice, forged when the women embrace the young men and invite them to become part of the collectivity, includes everyone who is willing to "begin again." "Women and the people march hand in hand" (131/189):

You understand that we have been fighting as much for you as for ourselves... Today, together, let us repeat as our slogan that all trace of violence must disappear from this earth... The young men [eux] applaud and shout [crient] with all their might. They have brought their arms. The women [elles] bury them at the same time as their own saying, let there be erased from human memory the longest most murderous war it has ever known, the last possible war in history. They wish the survivors, both male and female [aux survivantes et aux survivants], love strength youth, so that they [ils] may form a lasting alliance that no future dispute can compromise. One of the women begins to sing, Like unto ourselves / men who open their mouths to speak / a thousand thanks to those who have understood our language / and not having found it excessive / have joined with us to transform the world. (127-28/184) 
It is on this basis that the authorial narrator can also enter the narrative "we" to participate in a new order that is grammatically and philosophically feminine. In the final paragraph the narrative shifts simultaneously to a first-person plural voice and to the past tense that is the standard tense of realist narrative. Because of the linguistic transformations it evokes by feminizing all nouns and adjectives, I shall represent this passage in its entirety:

Mues par une impulsion commune, nous étions toutes debout pour retrouver comme à tatons le cours égal, l'unisson exaltant de l'Internationale. Une vieille soldate grisonnante sanglotait comme une enfant. Alexandra Ollontaï retenait à peine ses larmes. L'immense chant envahit la salle, creva portes et fenêtres, monta vers le ciel calme. La guerre est terminée, la guerre est terminée, dit à mes côtés une jeune ouvrière. Son visage rayonnait. Et lorsque ce fut fini et que nous restions là dans une sorte de silence embarrassé, quelqu'une au fond de la salle cria, camarades, souvenons-nous de celles qui sont mortes pour la liberté. Et nous entonnâmes alors la Marche funèbre, un air lent, mélancolique et pourtant triomphant. (207-8)

[Moved by a common impulse, we all stood to seek gropingly the even flow, the exultant unity, of the Internationale. An aged grizzled woman soldier sobbed like a child. Alexandra Ollontaï could hardly restrain her tears. The great song filled the hall, burst through doors and windows and rose to the calm sky. The war is over, the war is over, said a young working woman next to me. Her face shone. And when it was finished and we remained there in a kind of embarrassed silence, a woman at the end of the hall cried, Comrades, let us remember [those] who died for liberty. And then we intoned the Funeral March, a slow, melancholy and yet triumphant air.] (144)

This is the utopian "we" that "by a common impulse" "moves" the women and their male comrades to solidarity-to a "we" that has become possible, to quote Cherríe Moraga, only because "things [got] hot enough." It is a "we" open to all women and men who are able to refuse male hegemony. It is fitting that in signifying this "we" the text moves into the time and space of realist narrative: after the reclamation of language, the renaming of the world, representation can begin.

Yet the danger of traditional (Western) narrative is also exposed in this final, communal section of Les Guérillères because the passage recircumscribes the community as specifically Western, Marxist, and industrial. Avoiding the greatest danger of utopian literature, the 
production of stasis, Les Guérillères has been careful to show communities always in process, but since narrative closure is itself a kind of stasis, the shift to plural-voice past-tense narration that concludes Les Guérillères may be reinforcing a closure that is all too complete. That this passage is only a single moment after an entire book of present-tense, technically heterodiegetic narration is therefore also significant: if Les Guérillères transforms fantasy to history, no-time to our time, it must also stop with the single solemn moment when the "new" order begins. That the final singing of the Internationale takes place in a "hall" suggests a Western location, as the reference to Russian revolutionary Alexandra (K)Ollontaï suggests that it is Europe that is to lead the way out of injustice. Thus Europe becomes again the savior in a gesture that, however different its mission, can only reproduce the European colonialist project, and Les Guérillères, like any fiction, is revealed as the product of its own cultural positioning.

The limits implicit in the closing paragraph also suggest that the quasi-global communal authority of the rest of the text has depended on the novel's radical antinarrative form. As I pointed out earlier in my discussion, Les Guérillères succeeds in representing an inclusive feminist community precisely to the extent that it rejects not only traditional characters but the selectivity and hierarchies imposed by the choosing of protagonists, the constitution of a setting, and the traditional continuities of plot. By postulating a provisional textual authority against an order in which women are imprisoned in reified texts, Les Guérillères ultimately constitutes a radical critique not only of phallocentric discourse, and of a literature built on the silencing of female voice, but of those voices that women have inscribed in and as conventional literature. I argued earlier that the eighteenth-century heroine's voice, for all its outspokenness, was a silenced voice, allowed to speak only because of the sharp splits between the private and public, the novelistic and the political. Les Guérillères refuses this split between fictions of authority and the authority of the body politic and insists on the necessity to "WRITE VIOLENCE / OUTSIDE THE TEXT / IN ANOTHER WRITING [ECRIRE VIOLENCE / HORS TEXTE / DANS UNE AUTRE ECRITURE]" (143/205). In this sense Les Guérillères supports the implications of "self-silencing" eighteenthcentury novels such as Mistriss Henley and The Wrongs of Woman that that there is no viable fiction of authority unless it is also an authority "HORS TEXTE." It is appropriate, therefore, that Les Guérillères displaces the conventionally feminine alternatives of death and marriage 
with the alternatives death and liberty that have long been the male revolutionary imperative.

The "melancholy and yet triumphant" funeral song with which Les Guérillères concludes might then be an ode as well to the entire tradition of individual(ist) female voice: necessary but also necessarily sacrificed as "everything must begin over again" and a new "sun is about to rise" (66/131). It is fitting that since its publication in 1969 Les Guérillères has fostered not only a generation of utopian fiction but a generation of feminist theory as well, mapping a process of coming-to-community in language, a struggle for authority not only as "content" but as form, modeling the communal writing that is essential if this movement is to exist "hors texte," or in the world-astext. Wittig's book is a call not to deny the authority of fictions but, on the contrary, to recognize their power as representations by which women live and by which we may therefore reinvent our lives. Les Guérillères stands in this sense as a sign of feminist future, pointing to forms of narration that have perhaps not even been imagined, let alone expressed-forms that may give voice to women still not authorized. It is appropriate that Wittig's book invites its own readers to write the texts to come, for Les Guérillères is both the culmination of a Western novelistic tradition and the departure point for narrative possibilities as yet unknown.

We have so many voices to invent in order to express all of us, everywhere, even in our gaps, that all the time there is will not be enough.

-Luce Irigaray, This Sex Which Is Not One

It may seem that this book has given narrative voice an inordinate importance when, as Peter Brooks argues, most of us are "reading for the plot." I have tried to show that voice not only constructs and controls narrative but also enacts more-or-less visibly a "plot" of its own. Perhaps this "plot" has a particular importance for those 
whose voices have not been able simply to take for granted their discursive rights. I have emphasized public and private narrative voice, extrarepresentational acts, and self-conscious narrative strategies because I believe that for those without full discursive authoritythose who are not, to quote Dale Spender, able to "view all audiences and all forms of writing as open to them" - novels are able to constrain or to expand the possibilities for voice not only in other novels but in human history. As Chapter 1 suggested, narrative poetics has not, on the whole, concerned itself with these questions that are deeply intertwined with social authority; rather, in opting for a precise and esoteric terminology, it has ruptured the links between narrative and social practices. Likewise, feminist criticism has not, on the whole, attended to the complex interrelationship between representation and voice that, as my discussions of novels like Millenium Hall and Their Eyes Were Watching God have suggested, are sometimes ideologically at odds.

I said in Chapter 1 that each of the three modes allowed certain meanings and not others to be made visible and that all three forms seemed to me to have been necessary for women to make a place in Western literature. Although the emphasis of this book has been on women's achievement of forms that have been in some way prohibited, I hope I have pointed out the problems attendant on each of these narrative modes. Authorial voice, with its structurally superior position and its superhuman privilege, seems to me always in danger of constructing its own hegemony, yet it can be a powerful tool for dislodging an existing authority. The transformative power of Toni Morrison's Beloved, for example, seems to be the effect both of its overturning of white-realist authority and of its rich narrative polyphony, in which the "rememory" of slavery is created through a multiplicity of authoritative characters whose voices of ten merge in free indirect discourse with the authorial voice.

The differences I have tried to sketch between Jane Eyre's totalizing authority and Annie John's recognition of duplicity suggest the different textual effects that can be created through personal voice. Because its authority is more qualified, personal voice establishes a less certain hegemony, yet it has also the power to engulf the reader

6. Dale Spender, Man Made Language (London: Routledge, 1980), 193. 
in the vision of a single consciousness. If, on the other hand, the personal voice can represent itself as "interrogative," if it can, as Catherine Belsey puts it, "unfix" itself as subject," then "I" becomes a multiplicity of voices in dialogue. I think of Colette's La Vagabonde (1911), for example, as creating such a voice.

Although authorial and personal voice are unquestionably individual(ist) fictions, it seems to me that the construction of such individualist voices has been a necessary if insufficient revolutionary strategy in societies where the alternative to individualism has been oppression in the anonymity of caste. As my discussion of communal voice has indicated, however, there is perhaps a further political potential in forms that constitute the shared and at best also diverse vision of a community. But I have also argued that unlike authorial and personal voice, whose singularity corresponds to that of conventional authorship, communal voice arrogates to an individual author the selfreinforcing pretense of multiplicity.

Each of these three forms of voice-as well as other, hybrid narrative modes that $I$ have not been able to study here-is thus at once determined and open, restrictive and flexible, powerful and dangerous. Every narrative form is already a "content" in that the fact of its existence sends messages, but every narrative form is dependent for its value-hence in a crucial way for its meaning-on the contexts of representation and reception in which it is realized. It is my hope that as new and challenging forms of narrative voice come to be invented, new and supple forms of narrative theory will be able to account for them, so that the political project of finding voices and the theoretical project of naming them can join in the task of repairing the world.

7. Catherine Belsey, Critical Practice (London: Methuen, 1980), chap. 4 . 
